\title{
Taking a Stance: Teacher Researchers' Historical and Political Positioning
}

\author{
Elizabeth Currin \\ University of South Carolina \\ ecurrin@mailbox.sc.edu
}

\begin{abstract}
With teacher walkouts and other forms of protest on the rise, EdD programs are beginning to frame practitioner-scholars' work as activism. The purpose of this article is to explore and complicate that trend by interpreting data from oral history interviews with three long-term teacher researchers, alongside shifting historical scholarship on civil rights activism. Each participant cites civil rights activism as an inspiration and positions the rise of neoliberal education reform as a backlash to the 1960s that threatens the so-called teacher research movement. However, historians challenge the dominant narrative of the 1960s, highlighting behindthe-scenes conservative activism that did not garner the same media attention as liberal marches and boycotts. Consequently, while the participants' stories offer abundant insight for practitioner-scholars as well as for the teacher educators who guide them, this article ultimately argues EdD activists should take a schoolhouse-tostatehouse approach.

KEYWORDS: activism, teacher research, inquiry as stance, EdD programs, oral history
\end{abstract}

As teacher walkouts and other protests generate social electricity and garner media attention, EdD programs like mine are beginning to frame the work of practitioner-scholars as activism, a prospect that makes me both curious and cautious. For decades, Cochran-Smith and Lytle $(1993,2009)$ have emphasized the political nature of practitioner research, especially when driven by an inquiry stance. Inquiry stance is Cochran-Smith and Lytle's (2001) term for intentional, constant exploration of the "webs of social, historical, cultural, and political significance" in everyday classroom dilemmas (p. 50). Though teacher research is often described as an empowering movement (Brindley \& Crocco, 2009; Kinsler, 2010), we must consider "who is being empowered, by whom, and to what degree" (Klehr, 2009, p. 64). Indeed, teacher researchers are unlikely to come to teacher research on their own (Flessner \& Klehr, 2016; Perrillo, 2016), so we teacher educators should give careful thought to the implications of producing practitioner-scholar-activists. Particularly in this era of high-stakes testing, fraught with increasing efforts to control teachers' time, space, and very identities (Buchanan, 2015), there is a fine line between empowering and imposing.

This article takes up Klehr's (2009) call to investigate "the direction of the movement" (p. 64), acknowledging the long history of practitioner research and waning optimism for its future (Burnaford \& Hobson, 2001; Herr \& Anderson, 2015; Perrillo, 2016). Through a series of oral history interviews (Yow, 2005) with three long-term teacher researchers, I observed how despite different ages, backgrounds, and professional contexts, each cited civil rights activism as an inspiration. Further, they explained the rise of

neoliberal education reform as a backlash to the 1960s, $\mathbf{2 0}$ expressing considerable doubt about the future of practitioner research.

New articles in this journal are licensed under a Creative Commons Attribution 4.0 United States License.

My participants' narratives hold inherent value for teacher educators, illustrating how an inquiry stance can emerge and endure throughout a professional lifetime. However, this article proposes an alternate reading by troubling the 1960's schema employed by all three teacher researchers. Historians have challenged the dominant narrative of the 1960s, warning us not to ignore the behind-thescenes conservative activism and its long-lasting "political fruits" (Hijiya, 2003, p. 206). McGirr (2001), for example, attributed the "strength and endurance" of $20^{\text {th }}$-century conservatism to adherents' simultaneously proactive and reactive approach, a strategy that escaped recognition at the time, though it ultimately eclipsed the more well-known activism of the Left (p. 19). Consequently, Bessner (2019) recently challenged liberal scholars to resist the glamour of the grassroots, committing instead to "working within the strictures of the American political system" (para. 10). Similarly, Rust and Meyers (2007) once urged teacher researchers to move from schoolhouse to statehouse. This article recommends such an approach to EdD activists and their teacher educator allies.

\section{TEACHER RESEARCH: TRAITS, TRENDS, AND TRIBULATION}

Teacher research has several analogues, including action research and practitioner inquiry, all of which are rooted in the Progressive Era (Herr \& Anderson, 2015). Regardless of the label, the premise is the same, namely practitioners' articulating and systematically exploring authentic questions or problems related to their everyday work. In education, from the start, this practice promised "a different vision of the profession" (Perrillo, 2016, p. 91). By the end of the 20th century, supporters remained optimistic that

This journal is supported by the Carnegie Project on the Education Doctorate: A Knowledge Forum on the EdD (CPED) cpedinitiative.org 
"the image of teacher as researcher" had transformative potential (Burnaford \& Hobson, 2001, p. 236). The concept of inquiry as stance (Cochran-Smith \& Lytle, 2001, 2009) catalyzed the spread of teacher research, reinforcing belief in its capacity to transform the teaching profession (Ravitch, 2014). As noted earlier, teacher researchers with an inquiry stance exhibit constant curiosity about everyday classroom dilemmas, which they see as rooted in larger "webs of [...] significance" (Cochran-Smith \& Lytle, 2001, p. 50). Teacher research, scholars contend, thus positions practitioners "as members of a profession whose boundaries extend beyond the schoolhouse" (e.g., Bray et al., 2000, p. 77), who are likely, even in retirement, to be "politically active" on students' behalf (Dagenais et al., 2000, p. 102).

This was precisely the mission of the Teachers Network Leadership Institute (TNLI), an outgrowth of the Teachers Network, which arose in 1979 to address "the noticeable absence of the teachers' voice in education policy" (Rust \& Meyers, 2007, p. 71). The schoolhouse-to-statehouse initiative, which sought to recruit teacher researchers and train them to share their findings with policymakers, was marginally successful, contributing to "a growing body of research by teachers" (p. 69). Nevertheless, TNLI ultimately fell short of its political aims. Because teacher researchers may be hesitant or unable to pursue publication (Klehr, 2009), when they share their work, it is often in practitioner-focused or practitioner-only spaces. In other words, they are "essentially "preaching to the choir"' (Rust \& Meyers, 2007, p. 70). Arguably, this is the case with many scholarly circles, but in the case of scholarly practitioners, their relative lack of political and institutional power often stymies their ability to act on their own and each other's findings. Moreover, earnest attempts to spread teacher research run the risk of becoming top-down, tainted by the very accountability ethos teacher educators may urge teacher researchers to interrogate (Klehr, 2009). EdD programs, which invariably operate within institutional constraints and must impose specific requirements on their students, should be especially mindful of this dilemma and sensitive to our role as gatekeepers. Though we, too, face structural barriers in our own work, we inherently occupy positions of power over our students.

For various reasons, then, teacher researchers are hardpressed to engage in truly political inquiry (Charest, 2019), and far too many teachers "wholeheartedly embrace" the neoliberal status quo, with only the rare few "pushing back" (Buchanan, 2015, p. 715). While Dunn (2018) views teacher attrition as a significant form of resistance, by enlisting long-term teacher researchers with an inquiry stance, I sought a more optimistic route.

\section{THE CASE FOR TEACHER RESEARCHERS' TESTIMONIES}

Mirroring scholarship that frames teachers' memories in a historical way (e.g., Blumenreich \& Rogers, 2016), I used oral history (Yow, 2005) to examine the experiences of individual participants as well as to look across their narratives after obtaining approval from the University of Florida Institutional Review Board. Acknowledging that teacher researchers are born of teacher educators (Flessner \& Klehr, 2016), I solicited recommendations from teacher research scholars. Through an initial screening process, I obtained the consent of three participants, who all granted me permission to use their real names. Each teacher researcher participated in three semistructured interviews (Seidman, 2006), sharing their professional life stories, which I have condensed in this article. Given that "stories come from somewhere and go somewhere" (Clandinin, 2018, p. 19), the following testimonies are rooted in the 1960s, travel through the 1990s pinnacle of teacher research, and testify to a backlash in the present. This, I argue, has implications for the teacher research movement and for EdD activism.

\section{Cindy Ballenger: "A Teacher out of the '60s"}

Cindy point-blank introduced herself as "a teacher out of the '60s" and recounted her undergraduate years at Barnard College in New York City, one of those "hot, exciting places in those days politically." Though Cindy had enrolled in the late 1960s without setting foot on campus, her mother had visited and described "leaflets up all over the place for meetings for [...] different sorts of causes." These details promised a more "bohemian" or "multicultural" environment than she had experienced in suburban Illinois. After graduation, she got involved with the GI movement in opposition to the Vietnam War by working in a "GI coffeehouse" near Westover Air Reserve Base, a venue offering legal counseling and other advice for anti-war Gls.

As a teacher educator, I was struck by how divergent Cindy's narrative was from the typical teacher origin story. She eventually found her way to teaching by taking a job in a Massachusetts daycare, inspired, she thinks, by President Johnson's Great Society campaign as part of the War on Poverty. Through a series of career moves, by the 1980s, she connected with the Brookline Teacher Researcher Seminar (BTRS). A group founded by, for, and of teachers, BTRS focused on promoting open dialogue about "what wasn't working" in members' classrooms, a stark contrast from the dubious What Works Clearinghouse associated with accountabilityera education (Lynch \& Martin, 2017; Pampaka et al., 2016).

Eventually, though, the group disbanded, and Cindy struggled to recreate its magic. She recalls, "It was a better period. [...] Now it's hard to get teachers [...] to add another meeting. They don't have time." Pointing to a noticeable ebb in teacher research in the 21st century, Cindy suggested, 'It's nice that they're required in a whole range of programs, some sort of teacher research project, but [...] somehow, I don't get the sense that it sticks." Her experiences with BTRS, arguably rooted in her earlier days as an activist, impressed upon her the need for a fire in one's belly. Otherwise, Cindy reasoned, teachers might be tempted to play it safe, because inquiring into their challenges and mistakes is deeply uncomfortable, especially now. The accountability climate, according to Cindy, causes teachers to feel "overwhelmed." For example, she pointed to "so many meetings in order to make sure the curriculum is getting done" and suggested having such a full schedule results in "not enough time to think." When Cindy increasingly observed these trends, this "teacher out of the '60s" ultimately decided to retire.

Even in retirement, though, Cindy continues to work in schools, where her activism manifests in advocacy:

It's almost impossible not to see deficits, [...] but now with this testing stuff, I just don't think there's any way to resist it unless you've got the kind of focus on places where kids take initiative, which is what I mean by the kind of discussion I try to do where kids say what's on their mind and that can sort of shatter this view of kids being full of deficits.

Cindy uses these insights to lobby for students' needs, wielding "story as [a] weapon" to improve teaching and learning by "telling [teachers and administrators] stories about the kids that they don't see." This resistance on Cindy's part is but one example of her 
commitment to more equitable education, reflective of her enduring inquiry stance. Cindy rejects the idea that wherever there is "a looseness, [...] we have to tighten up." In doing so, she openly challenges the strict and standardized status quo, continuing to engage in inquiry at every opportunity.

\section{Gail Ritchie: "An Old Liberal Softy”}

Like Cindy, Gail also took a winding path to the classroom, quite literally in the sense that she was an "army brat." The family's transience, she believes, actually nurtured her inquiry stance, in part because it brought her into contact with so many different school contexts -- including desegregation-era busing -- and teaching styles. In high school, for example, she enjoyed learning from a bona fide poetess, "a very quirky [...] hippie" with "super-long" hair and "fringy, loose-flowing caftan kind of clothes." Even though she went on to teach much younger students, Gail intentionally embraced a similarly "open-ended and differentiated" pedagogy -- once she actually answered the call to teaching.

After graduating high school at "the height of [the] Watergate" Era, Gail accepted an ROTC scholarship to Northwestern. She described this time period as "the tail end of the anti-Vietnam era" and recalled a lot of "liberal disdain for the military." In Gail's case, this manifested in the ROTC building's intentionally off-campus location. Consequently, she "didn't really advertise [...] or brag about" her involvement with ROTC, knowing how her father had been advised to wear civilian garb even when stationed at the Pentagon. At the time, her "sorority sisters thought it was really weird [...] to be affiliated with the military." At a recent reunion, however, several of them, out of nowhere, expressed gratitude to Gail for her service, which "never would have happened in those days." Instead, she shared, "you'd be more likely to be spit on." Gail suspected their politics have taken a rightward turn, whereas she never fell prey to the specious logic that conflates military service and a conservative voting record, having grown up "on posts and with liberal parents." Owing to the end of the draft, Gail reasoned, "times have changed."

Over the course of her career, times definitely changed, as Gail witnessed a proliferation of "education policies that don't align with beneficial teaching and learning." Particularly in the wake of No Child Left Behind, she cites a "domino effect of standards' becoming more rigorous so that kids could be tested against those more rigorous standards." All too often, this means "one subject at a time, kind of trying to dump knowledge into kids' heads, which is contrary to what we know about how the brain learns." Like Cindy, Gail is retired, but that does not prevent her from worrying about "people in the trenches who do understand how people learn but are being forced to act in ways that are contrary to their beliefs and knowledge systems."

Gail feels at odds with "who's in power right now nationally" because she identifies as "an old liberal softy." She claimed:

If I were the Secretary of Education, I definitely would be approaching it very differently than the current one. [...] I would definitely promote an inquiry-based, introspective, ongoing, always curious approach to teaching and learning, and I think researching one's own practice is an integral part of that.

Of course, Gail is not likely to face a Senate confirmation hearing any time soon, and even in her district, she "was never in a powerful enough position" to fully actualize her vision for teacher research and ensure it "hasn't completely died out."
Gail did her level best, including participating in the local Teacher Researcher Network during its "glory days." Subsequent personnel changes and financial hardship destroyed "the final vestige of any kind of support" for teacher research, and though Gail had joined the nationwide Teachers Network Leadership Institute, it "disbanded [...] once the accountability movement really got underway." Even in retirement, she continues to work in schools and advocate for public education, though her political activism is "not to the point of, like, marching in things." Still, Gail's inquiry stance continues to align with her tendency to be "definitely progressive and liberal in viewpoint."

\section{Erik Shager: "The Opposite of Scott Walker and His IIk"}

Of my three participants, Erik Shager is the only one without any actual memories of the 1960s, yet he has always felt an ideological kinship with civil rights activists. As an undergraduate, for example, he explored "the history of African-Americans in Wisconsin" and examined "urban unrest in the '60s." He proudly referenced these projects when seeking admission to a graduate program in education. Likewise, when he took his first teaching job at an alternative high school, he appreciated how it "arose in the '60s, out of a [...] progressive education kind of philosophy." He explained, "the first alternative ed. program in Madison, City School, was basically taught by a bunch of hippies." Despite being too young to have been a hippie himself, Erik has fond memories of working in that context and always felt comfortable "experimenting and trying new things" or "coming up with an idea and running with it." He knew he would be expected to account for his students' learning, adding, "you were empowered, but you were also, you know, responsible."

That crucial balance of support and "flexibility to do cool things" was also present in the district's "action research groups." Erik's group encouraged him to pursue whatever he was "passionate about" and made him feel as though leaders were interested in his research findings. Whenever "some initiative" came teachers' way, Erik would "blend" it with teacher research. In fact, one of his most extensive teacher research projects engaged his students as coresearchers within an existing "social issues unit." This allowed him to apply his inquiry stance in a way that "fit a lot of what was expected" in terms of state standards. The students explored one set of research questions: "Why are students dropping out of high school [...] and specifically why are kids of color dropping out at a higher rate?" Erik acted as "kind of a facilitator" while simultaneously "researching their research." To guide his inquiry, he wondered, "When students do these social issues projects [...], what's actually happening as they're going through that process, and what can we learn from it?" He and his students relished this experience.

In his alternative school, Erik was somewhat shielded from the initial onslaught of neoliberal education reform, but eventually, it caught up to him. In contrast to the beginning of his career, he now experiences more "oversight" and feels he has "to really massage the benchmarks" to do anything creative. He shared, "The thought of, 'Hey, I'm going to do this action research project, which involves me changing up the curriculum a little bit,' [...] that just wouldn't happen." Everything feels "more centralized, you know, [...] a lot of that [...] running the trains on time [...] kind of talk." As elsewhere, "There's just a little more of that top-down stuff." This makes Erik feel "locked in" and compelled "to teach a certain way." Though he firmly believes alternative education should provide students with unique and 
differentiated alternatives, he is expected to align his curriculum with that of a similar school in the district. He explained, "Pretty much what I'm supposed to do today is the same thing the guy across town is doing."

Needless to say, this chafes at Erik's inquiry stance, because he prefers "more of a discussion-based classroom, more inquirybased." He added, "I'm definitely in my element when I can bounce around and know that kids are connecting on something and working through it on their own, rather than [...] 'sit and get' kind of stuff." He dreams of curricular freedom to incorporate his activist interests in the classroom:

I would love to do a civil rights class, not just the history of civil rights. It could be something on social movements that would encompass [...] stories of people who had to [...] use the tools that were [...] not always granted in the Constitution [...] to change society, to ask America to live up to its ideals.

Given Madison, Wisconsin's rich history of social movements, especially those involving students, such a course might "really hook" his students, inviting them to discuss present injustices and serving as a way to "get through some of the cynicism that people have" by showing them how "you can make change...that you really can do it."

Unlike Cindy and Gail, Erik has yet to retire, so he has to be more mindful of the expectations for teachers, even when he disagrees. Still, as a teacher researcher with an inquiry stance, he remains vigilant and committed to improving for the sake of his students. To him, that means carrying forward the legacy of the civil rights movement, even by taking to the streets, and he is proud to be "the opposite of Scott Walker and his ilk." Indeed, Erik belongs to the union that vociferously challenged Act 10 , the so-called budget repair bill that effectively "launched a war on labor" through sharp cuts to insurance benefits, pension plans, and collective bargaining rights (Strauss, 2018, para. 1). Erik decried this ultraconservative Tea Party "wave" and the ensuing "cutbacks across the board." He felt he and his like-minded colleagues had "a target on [their] back." Nevertheless, he persisted in the courage of his convictions. He recalls "having to explain to students why you walked out or [...] why they had 3 days off. It was great." For Erik, then, being a teacher researcher is inherently compatible with being an education activist.

\section{MAKING SENSE WITH AND OF THE SIXTIES}

To oral historians, "how people foresee the future can also influence their presentation of the past" (Slim \& Thomson, 1995, p. 140). As the narratives above attest, my participants all identified a decline in teacher research accompanying the rise of neoliberal education reform, which they understood as a backlash to the 1960s, the very decade that inspired their identities as change agents and, in their view, resonated in their research. Their insights echo Nichols and Cormack's (2016) argument that the height of teacher research was during the "'hippy age' of teaching" (para. 1). Conversely, the onset of high-stakes testing and the top-down promotion of evidence-based practice hastened its demise. In spite of efforts throughout the 1960 s and 1970 s to enact social progress "in schools, and by extension in society" (Sugimoto \& Carter, 2016, p. 21), the 1983 bombshell $A$ Nation at Risk resulted in a policy preference for excellence over equity (Kamenetz, 2018). In other words, neoliberalism's rise encompassed an intentional rollback of the civil rights era (Hall, 2005; Hijiya, 2003), which schools experienced acutely.
Despite or in some cases because of such contextual constraints, Cindy, Gail, and Erik continued to engage in teacher research, identifying problems of practice that invariably contained traces of this backlash. Whereas problem has a pejorative connotation in general conversation, for teacher researchers, problematizing is the path to progress, akin to John Lewis's (2018) framing his civil rights activism as "good trouble" (para. 5). Lewis's credo continues to resonate with today's teacher activists (e.g., Egan, 2019; Parmenter, 2019), so imagining teacher research as activism is not entirely a conceptual leap.

On the other hand, given the enduring stronghold of conservative political power throughout the United States, advocates of teacher research may benefit more from examining the emergence of that stronghold, namely the activities of Lewis's (2018) civil rights era contemporaries who were engaging in trouble of a different sort. Rather than reading these teacher researchers' tales of the bygone glory days in dismay, we can look to the lesser-known narratives of the 1960s for lessons on how to revive the promise of practitioner research.

For instance, Andrew (1997) challenged the dominant narrative of civil rights activism in the "almost mythic decade" of the 1960 s by shifting the scholarly gaze from the Left to the Right, whose efforts actually "outlasted the decade" (p. 1). Chronicling the Young Americans for Freedom as the Right's version of the Student Nonviolent Coordinating Committee, he repositioned the Reagan Revolution as a patient "triumph of organization" (p. 6), suggesting the conservative reforms of the 1980 s had decidedly 1960 s roots. Consequently, "Unlike the Left, whose organizational energies and spirit seemed to have died by the end of the sixties, the Right was just beginning to flex its muscles" (p. 220).

Likewise, McGirr (2001) cited the media's attraction to "the more flamboyant Left" to argue such lop-sided coverage "distorted our understanding of American conservatism" (pp. 6-7). To counter that story, she positioned the ascendant Right as a successful social movement:

Locally, mobilization involved the grassroots leaders and rankand-file men and women, the broader ideological waters in which they swam, as well as regional business elites who offered resources and institutional support. At the national level, it involved the formation of an intellectual leadership that sought to give cohesion to the ideas underpinning the movement, as well as a political leadership that offered direction to channel conservative sentiment. (p. 12)

Hijiya's (2003) work on this "secret history of the 1960s" argued the Right may have been complacent in its obscurity (p. 202). While the counterculture captured the headlines, the counter-counterculture "began their long march through the institutions of society" and ultimately succeeded in "building, capturing, and preserving organizations" (p. 203).

This expansion of 1960 s scholarship can inform our view of that decade's legacy. Amid the scholarly shift, Eynon (1996) encouraged the use of oral history, which could "reveal the roots of activism" and ultimately "provide clues to the legacy of the movements" (pp. 560561). Relying on media accounts, as earlier scholars had done, produced "closed narratives in which the story was familiar and the answers known" (p. 562). The Right understood the power of story and began crafting "a large-scale tale, a cultural narrative, a vision of what America is and what it should do" (Ricci, 2011, p. 4).

Practitioner-scholars have these skills, so their "small stories [might also] appear, merge, and culminate [...in] a sweeping narrative" with 
political power (p. 159). In other words, might EdD activism manifest in patient and systematic efforts to achieve and maintain direct influence on education policy? Might scholarly practitioners progress from schoolhouse to statehouse?

\section{IMPLICATIONS FOR THE SO-CALLED TEACHER RESEARCH MOVEMENT}

Detecting "a strange absence of teachers' own testimony" in discussions of education policy, Robinson (2019) recently argued, "If you trusted teachers, you would ask them to propose the methods they thought would most improve students' experiences" (para. 12). In theory, EdD programs strive for this ideal, yet teacher researchers' impact at the "state and/or federal level" (Rust \& Meyers, 2007, p. 80 ) has yet to be fully actualized. If we desire truly impactful EdD activism, we would do well to notice the New Right's patience-and its payoff. As Hijiya (2003) argued, "The New Left's power resided in its actions, not its organizations. The New Right was different. For conservatives power came through a position, a public office, a job" (p. 206).

Although each of my participants referenced and relied on the dominant narrative of the 1960s, this lesser-known narrative might provide an ironically instructive model. Cindy's anti-war activism positioned her as "a teacher out of the '60s." Similarly, Gail described herself as "an old liberal softy." Despite being the youngest of the three, Erik exhibited a profound interest in civil rights history, which echoes in his willingness to march with fellow union members. Thus, all of their stories attest to the "apparently radical" nature of teacher research, the recognition that teachers can "understand, question and change what goes on in classrooms and schools" (Klehr, 2009, p. 4). However, perhaps the most radical move a teacher researcher could make would be to take a page from the conservative playbook. Indeed, activists must ultimately "channel grass-roots anger toward specific policy goals" (Bessner, 2019, para. 17). If EdD students -and the teacher educators who guide them -- wish to position themselves as activists, they must acknowledge that historically, successful practitioner research has been "neither grassroots nor ad hoc" (Perrillo, 2016, p. 93). Any discussion of EdD activism therefore, must imagine how practitioner-scholars can infiltrate and transform America's political institutions.

Cindy, Gail, and Erik are living proof that "the stories we tell about the civil rights movement [...] shape how we see our own world" (Hall, 2005, p. 1239). Their stories, in turn, can shape how teachers and teacher educators see and understand teacher research. Just as oral histories of the 1960 s revealed "the changing ways that activists and others understood the world and their place in it" (Eynon, 1996, p. 565), I have sought, through teacher researchers' testimonies, to broaden our understanding of the teacher research movement, even to the point of wondering whether or not it is a movement.

A decade ago, Klehr (2009) acknowledged the "exciting" prospect of framing "teacher research as a grassroots, autonomous effort belonging to teachers" and cautioned, "we cannot claim that vision as a reality just yet" (p. 66). Teacher research continues to be an attractive and ostensibly empowering concept, although that latter descriptor still necessitates "a broader conversation" (Dodman et al., 2017 , p. 42). This article, by taking a long view of how teacher researchers position themselves and their work, offers some insight, along with an invitation to keep the conversation going.

\section{NOTE}

The author wishes to thank the University of Florida Center for the Humanities and the Public Sphere for the Rothman Doctoral Fellowship that made this research possible.

\section{REFERENCES}

Andrew, J. A. (1997). The other side of the sixties: Young Americans for Freedom and the rise of conservative politics. Rutgers University Press.

Bessner, D. (2019, February 27). The academy is unstable and degrading Historians should take over the government, instead. The Chronicle of Higher Education. Retrieved from https://www.chronicle.com/article/TheAcademy-Is-Unstable-and/245778

Blumenreich, M., \& Rogers, B. (2016). TFA and the magical thinking of the 'best and the brightest'. Education Policy Analysis Archives, 24(13), 1 31. https://doi.org/10.14507/epaa.24.1926

Bray, J. S., Kramer, P. A., \& LePage, D. (2000). The expert teacher. In B. E. Steffy, M. P. Wolfe, S. H. Pasch, \& B. J. Enz (Eds.), Life Cycle of the Career Teacher (pp. 75-84). Thousand Oaks, CA: Corwin Press.

Brindley, R., \& Crocco, C. (Eds.). (2009). Empowering the voice of the teacher researcher: Achieving success through a culture of inquiry. Rowman \& Littlefield Education.

Buchanan, R. (2015). Teacher identity and agency in an era of accountability. Teachers and Teaching: theory and practice, 21(6), 700-719. https://doi.org/10.1080/13540602.2015.1044329

Burnaford, G. E., \& Hobson, D. (2001). Responding to reform: Images for teaching in the new millennium. In P. B. Joseph \& G. E. Burnaford, Images of schoolteachers in America (pp. 229-243). L. Erlbaum Associates.

Charest, B. (2019). Navigating the shores: Troubling notions of the teacher as researcher. International Journal of Critical Pedagogy, 10(2), 19-43. Retrieved from http://libjournal.uncg.edu/ijcp/article/view/1900

Clandinin, D. J. (2018). Reflections from a narrative inquiry researcher. LEARNing Landscapes, 11(2), 17-24. https://doi.org/10.36510/learnland.v11i2.941

Cochran-Smith, M., \& Lytle, S. L. (1993). Inside/outside: Teacher research and knowledge. Teachers College Press.

Cochran-Smith, M., \& Lytle, S. L. (2001). Beyond certainty: Taking an inquiry stance on practice. In A. Lieberman \& L. Miller (Eds.), Teachers caught in the action: Professional development that matters (pp. 45-58). Teachers College Press.

Cochran-Smith, M., \& Lytle, S. L. (2009). Inquiry as stance: Practitioner research for the next generation. Teachers College Press.

Dagenais, R. J., Steffy, B. E., \& Enz, B. J. (2000). The emeritus teacher. In B. E. Steffy, M. P. Wolfe, S. H. Pasch, \& B. J. Enz (Eds.), Life cycle of the career teacher (pp. 96-103). Corwin Press.

Dodman, S., Groth, L., Ra, S., Baker, A., \& Ramezan, S. (2017). Developing an inquiry stance through PDS action research: Does it maintain after graduation? School-University Partnerships, 10(4), 30-46.

Dunn, A. H. (2018). Leaving a profession after it's left you: Teachers' public resignation letters as resistance amidst neoliberalism. Teachers College Record, 120(9), 1-35.

Egan, S. (2019, July 19). Why we need to allow teachers to get into 'good, necessary trouble.' Caffeinated Rage. Retrieved from https://caffeinatedrage.com/2019/07/19/why-we-need-to-allow-teachersto-get-into-good-necessary-trouble/

Eynon, B. (1996). Cast upon the shore: Oral history and new scholarship on the movements of the 1960s. Journal of American History, 83(2), 560570. https://doi.org/10.2307/2944948

Flessner, R., \& Klehr, M. (2016). Lessons from the teaching of teacher research. Educational Forum, 80(4), 479-480. https://doi.org/10.1080/00131725.2016.1208024

Hall, J. D. (2005). The long civil rights movement and the political uses of the past. The Journal of American History, 91(4), 1233-1263 https://doi.org/10.2307/3660172

Herr, K., \& Anderson, G. L. (2015). The action research dissertation: A guide for students and faculty (2nd ed.). Sage. 
Hijiya, J. A. (2003). The conservative 1960s. Journal of American Studies, 37(2), 201-227. https://doi.org/10.1017/S0021875803007072

Kamenetz, A. (2018, April 29). What 'A Nation At Risk' got wrong, and right, about U.S. schools. National Public Radio. Retrieved from https://www.npr.org/sections/ed/2018/04/29/604986823/what-a-nation-atrisk-got-wrong-and-right-about-u-s-schools

Kinsler, K. (2010). The utility of educational action research for emancipatory change. Action Research, 8(2), 171-189. https://doi.org/10.1177\%2F1476750309351357

Klehr, M. R. (2009). Artful inquiry: Aesthetic practices in teacher research. (Doctoral dissertation). Retrieved from ProQuest Dissertations and Theses database. (UMI No. 3399992)

Lewis, J. (2018, January 4). Why getting into trouble is necessary to make change. TIME. Retrieved from https://time.com/5087349/why-gettinginto-trouble-is-necessary-to-make-change/

Lynch, J., \& Martin, N. (2017, February 12). Why 'What Works' doesn't: False positives in education research. EdSurge. Retrieved from https://www.edsurge.com/news/2017-02-12-why-what-works-doesn-tfalse-positives-in-education-research

McGirr, L. (2001). Suburban warriors: The origins of the new American Right. Princeton University Press.

Nichols, S., \& Cormack, P. (2016, November 7). Teacher research and why it is more important than ever for our schools. EduResearch Matters. Retrieved from https://www.aare.edu.au/blog/?p=1838

Pampaka, M., Williams, J., \& Homer, M. (2016). Is the educational 'What Works' agenda working? Critical methodological developments. International Journal of Research \& Method in Education, 39(3), 231 236. https://doi.org/10.1080/1743727X.2016.1170476

Parmenter, J. (2019, July 19). About Istation's threats of legal action against NC educators. Notes from the Chalkboard. Retrieved from http://notesfromthechalkboard.com/2019/07/19/about-istations-threats-oflegal-action-against-nc-educators/

Perrillo, J. (2016). Between the school and the academy: The struggle to promote teacher research at Columbia University's Lincoln School, 1917 1935. History of Education Quarterly, 56(1), 90-114 https://doi.org/10.1111/hoeq.12150

Ravitch, S. M. (2014). The transformative power of taking an inquiry stance on practice: Practitioner research as narrative and counter-narrative. Penn GSE Perspectives on Urban Education, 11(1), 5-10.

Ricci, D. M. (2011). Why conservatives tell stories and liberals don't: Rhetoric, faith, and vision on the American right. Paradigm Publishers.

Robinson, N. J. (2019, February 6). The kind of policy we must never make again. Current Affairs. Retrieved from https://www.currentaffairs.org/2019/02/the-kind-of-policy-we-must-nevermake-again

Rust, F., \& Meyers, E. (2007). The bright side: Teacher research in the context of educational reform and policy-making. Teachers and Teaching: theory and practice, 12(1), 69-86. https://doi.org/10.1080/13450600500365452

Seidman, I. (2006). Interviewing as qualitative research: A guide for researchers in education and the social sciences (3rd ed.). Teachers College Press.

Slim, H., \& Thomson, P. R. (1995). Listening for a change: Oral testimony and community development. New Society Publishers.

Strauss, V. (2018, July 3). A new public education movement is emerging in Wisconsin, a rebuke to Gov. Walker's war on labor and school privatization. The Washington Post. Retrieved from https://www.washingtonpost.com/news/answer-sheet/wp/2018/07/03/anew-public-education-movement-is-emerging-in-wisconsin-a-rebuke-togov-walkers-war-on-labor-and-school-privatization/?noredirect=on

Sugimoto, A. T., \& Carter, K. (2016). Divergent narratives: The story of schools, schooling, and students from the 1960s to the present. In K. Bosworth (Ed.), Prevention science in school settings: Complex relationships and processes (pp. 19-32). Springer.

Yow, V. R. (2005). Recording oral history: A guide for the humanities and social sciences (2nd ed.). AltaMira Press. 